\title{
SEMIOTIKA VISUAL KARYA LUKISAN PENGIDAP SKIZOFRENIA
}

\author{
William Darmawan ${ }^{1)}$, Syahrul Ramadhan ${ }^{2)}$ \\ Program Studi Desain Komunikasi Visual, \\ Fakultas Bahasa dan Seni, Universitas Indraprasta PGRI \\ Jl. Nangka No. 58 C, Tanjung Barat, Jakarta Selatan, 12530, Indonesia
}

Arul11d99@gmail.com

\begin{abstract}
Abstrak
Setiap orang pasti mempunyai mental yang berbeda-beda, ada yang kuat dan ada pula yang lemah. Begitu juga ada orang yang mempunyai mental yang sehat, dan juga mental yang sakit tergantung dari faktor lingkungan dan kesehatan yang ada, juga faktor masa lalu yang pernah dialami oleh orang tersebut. Namun, karena kurangnya pengetahuan kita dalam mengetahui berbagai penyakit jiwa, hal tersebut menjadi disepelekan oleh berbagai pihak dan menganggap penyakit jiwa hanyalah masalah kecil saja. Seperti contohnya penyakit jiwa skizofrenia yang selalu dianggap penyakit yang tidak logis bagi kebanyakan masyarakat. Penelitian ini bertujuan untuk menginformasikan dan menjelaskan penyakit jiwa skizofrenia dan apa arti dari karya seni yang diciptakan oleh pengidap skizofrenia menggunakan teori semiotika. Dalam menyelesaikan penulisan ilmiah kami, kami menggunakan metode kualitatif dengan hasil penelitian berdasarkan sumber premier dari salah satu narasumber yang menekuni ilmu psikologi jiwa dan sumber sekunder dari beberapa artikel pada jurnal atau website yang menjelaskan fakta mengenai penyakit jiwa skizofrenia dan juga teori semiotika yang digunakan menurut para ahli sehingga masyarakat mengetahui informasi tersebut dan tidak menyepelekan penyakit jiwa, khususnya penyakit skizofrenia dan mengerti apa yang dirasakan para pengidap melalui karya seni yang diciptakan.
\end{abstract}

Kata Kunci: Psikologi, Skizofrenia, Semiotika, Karya Seni

\begin{abstract}
Everyone must have a different mentality; some are strong, and some are weak. Likewise, there are people who are mentally healthy, and also mentally ill depending on existing environmental and health factors, as well as past factors that the person has experienced. However, due to our lack of knowledge in knowing various mental illnesses, it has become underestimated by various parties and considers mental illness to be just a minor problem. For example, schizophrenia mental illness is always considered an illogical disease for most people. This study aims to inform and explain schizophrenia and mental illness and what is the meaning of the artwork created by the schizophrenic using the theory of semiotics. In completing our scientific writing, we use qualitative methods with research results based on premiere sources from one of the sources who are engaged in mental psychology and secondary sources from several articles in journals or websites that explain facts about mental illness schizophrenia and also the semiotic theory used according to the authors. experts so that the public knows the information and does not underestimate mental illness, especially schizophrenia and understands what sufferers feel through the artwork they create.
\end{abstract}

Keywords: Psychology, Schizophrenia, Semiotics, Artwork

Correspondence author: Name, E-mail, City, and Country 


\section{PENDAHULUAN}

"Mens Sana In Corpore Sano" atau yang diartikan sebagai di dalam tubuh yang kuat, terdapat jiwa yang sehat itu yang dikatakan oleh Decimus Lunius Juvenalis (Satire X, abad ke-2 Masehi). Setiap manusia memiliki jiwa dan raga yang saling berdampingan satu sama lain, karena jika jiwa seorang manusia tidak sehat, maka raganya pun akan goyah dan tidak dapat berjalan dengan baik. Maka dari itu jiwa dan raga merupakan satu kesatuan yang tidak dapat dipisahkan sama sekali. Sama halnya dengan seluruh anggota tubuh dan organ kita, jika salah satu dari organ tersebut tidak berfungsi dengan baik, maka organ yang lainnya pun akan ikut terkena dampak dari hal tersebut dan tubuh tidak berjalan dengan semestinya. Jiwa amat dekat sekali kaitannya dengan ilmu psikologi. Menurut Chaplin dalam Dictionary of Psychology (1972), Psikologi adalah ilmu pengetahuan mengenai perilaku manusia dan hewan, juga penyelidikan terhadap organisme dalam segala kerumitannya ketika bereaksi arus dan perubahan alam sekitar dan peristiwaperistiwa kemasyarakatan yang mengubah lingkungan. Dan pastinya sangat erat sekali kaitannya dengan jiwa, begitu juga dengan penyakit kejiwaan.

Jiwa atau Jiva berasal dari bahasa Sanskerta yang artinya "benih kehidupan". Dalam berbagai agama dan filsafat, jiwa adalah bagian yang bukan jasmaniah (immaterial) dari seseorang. Biasanya jiwa dipercaya mencakup pikiran dan kepribadian dan sinonim dengan roh, akal, atau awak diri (Soul, 2008). Menurut KBBI, jiwa memiliki arti roh manusia (yang ada di di tubuh dan menyebabkan seseorang hidup atau nyawa. Jiwa juga diartikan sebagai seluruh kehidupan batin manusia (yang terjadi dari perasaan, pikiran, angan-angan, dan sebagainya). Jiwa merupakan salah satu faktor terpenting pada raga manusia, karena tanpa jiwa yang sehat, kita tidak dapat berfikir dengan baik dan akan kehilangan akal sehat kita. Jiwa yang baik, pasti akan menimbulkan stimulan yang baik juga untuk sekujur tubuh dan memberikan energi yang baik pula sehingga tubuh kita dapat berfungsi dengan baik dan teratur. Namun, jika jiwa tersebut sakit dan tidak berjalan dengan normal. Maka dapat mempengaruhi kinerja seluruh tubuh lewat pikiran, dan alhasil dari pikiran tersebutlah kinerja otak kita tidak berfungsi dengan baik dan kacau dengan adanya gangguan jiwa yang tidak sehat. Setiap orang mempunyai kadar jiwa yang berbeda-beda, ada yang bisa dengan sabar dan mengontrol jiwa dan emosinya dengan baik.

Akan tetapi, ada juga orang yang mempunyai jiwa yang lemah dan tidak dapat mengontrol emosinya sehingga jiwanya akan mudah sekali untuk goyah dan tidak dapat dikontrol dan menimbulkan stress. Stress berasal dari bahasa latin Stinger, yang digunakan pada abad XVII untuk menggambarkan kesukaran, penderitaan dan kemalangan. "Stress adalah ketegangan atau tekanan emosional yang dialami seseorang yang sedang menghadapi tuntutan yang sangat besar, hambatan-hambatan, dan adanya kesempatan yang sangat penting yang dapat mempengaruhi emosi, pikiran dan kondisi fisik seseorang" (Marihot Tua Efendi Hariandja (2002:303). Stress bisa datang dari mana saja, dapat dari pekerjaan, faktor lingkungan sekitar, keluarga, tekanan hidup, teman, dan masih banyak lagi hal yang dapat menimbulkan stress itu sendiri. Dan dari stress tersebut, bisa menimbulkan penyakit gangguan jiwa (dalam Tunjungsari, 2011).

Gangguan jiwa menurut Depkes RI (2010) adalah suatu perubahan pada fungsi jiwa yang menyebabkan adanya gangguan pada fungsi jiwa yang menimbulkan penderitaan pada individu dan hambatan dalam melaksanakan peran sosial. Gangguan jiwa atau mental illness adalah kesulitan yang harus dihadapi oleh seseorang karena hubungannya dengan orang lain, kesulitan karena persepsinya tentang kehidupan dan sikapnya terhadap dirinya sendiri-sendiri (Budiman, 2010). Orang yang terkena gangguan jiwa, dalam kondisi awalnya biasanya akan sangat susah untuk berfikir dengan logis, cermat, dan fleksibel dikarenakan dengan tekanan yang mempengaruhi daya kerja otaknya dalam mengambil keputusan, yang dapat disebabkan karena penuh dengan keraguan dan ketidakpastian sehingga pengidap akan merasa khawatir dan tidak yakin dengan dirinya sendiri. Orang yang terkena gangguan jiwa bukan berarti gila, penyakit gangguan jiwa ada sangat banyak sekali dan bermacam-macam faktor penyebabnya dan jenis penyakitnya. Namun sayangnya, mereka tidak mengetahui seperti apa gejala-gejala dari penyakit jiwa itu dan kebanyakan masyarakat selalu menyepelekan penyakit gangguan jiwa sehingga ada banyak sekali orang yang tidak peduli dengan kesehatan jiwa mereka sendiri dan akhirnya menjadi korban dari tekanan batin yang diterima oleh faktor sekitarnya. 
Namun, meskipun korban mengidap gangguan jiwa, tidak jarang jika pengidap mengubah yang mereka rasakan ke dalam sebuah lukisan, dan di dalam lukisan itulah mereka mencurahkan ekspresi dan semua isi perasaan yang mereka rasakan agar orang-orang yang melihatnya pun tau jika itu yang mereka rasakan sebenarnya atau hal tersebut lah yang mengganggu mereka semasa mereka mengidap penyakit jiwa tersebut.

\section{METODE PENELITIAN}

Metode kualitatif menurut Sugiyono (2011), metode penelitian kualitatif berlandaskan pada filsafat positivisme, digunakan untuk meneliti pada kondisi objek yang alamiah, dimana peneliti adalah sebagai instrumen kunci, pengambilan sample sumber data dilakukan secara bermakna. Teknik pengumpulan data dengan gabungan analisis data bersifat induktif atau kualitatif, dan hasil penelitian kualitatif dan hasil penelitian kualitatif lebih menekankan makna daripada generalisasi.

Kami menggunakan metode kualitatif dengan hasil penelitian berdasarkan sumber premier dari salah satu narasumber yang menekuni ilmu psikologi jiwa dan sumber sekunder dari beberapa artikel pada jurnal atau website yang menjelaskan fakta mengenai penyakit jiwa skizofrenia dan juga teori semiotika yang digunakan menurut para ahli Sehingga masyarakat mengetahui informasi tersebut dan tidak menyepelekan penyakit jiwa, khususnya penyakit skizofrenia dan mengerti apa yang dirasakan para pengidap melalui karya seni yang diciptakan.

\section{HASIL DAN PEMBAHASAN}

Skizofrenia merupakan gangguan jiwa yang paling banyak dialami oleh beberapa orang dibandingkan penderita gangguan jiwa lainnya yang umumnya menyerang pada usia produktif dan merupakan penyebab utama disabilitas kelompok usia 15-44 tahun (Davison, 2005). Menurut Irmansyah (dalam Nainggolan, 2013) di Indonesia diperkirakan sekitar 30.000 orang penderita skizofrenia harus di pasung dengan alasan agar tidak membahayakan orang lain atau untuk menutupi aib keluarga, namun hal ini justru memperparah keadaan pasien itu sendiri. Karena, pengidap skizofrenia bisa membahayakan lingkungan di sekitar akibat halusinasi atau delusi yang dialaminya dan mempengaruhi mereka untuk bertindak dan melakukan apapun secara spontan.

Skizofrenia tidak hanya menjadi gangguan yang banyak dialami, gangguan ini adalah salah satu gangguan jiwa dengan output kesembuhan yang kurang begitu baik. Dikarenakan dalam penyembuhan penyakit tersebut memerlukan terapi yang khusus dan bahkan, pengobatan tersebut tidak membuahkan hasilnya. Sampai saat ini para ahli belum mendapatkan kesepakatan tentang definisi baku dari kekambuhan skizofrenia. Dikarenakan pengidap bisa saja kambuh kapan saja tanpa alasan yang jelas saat pengidap dipertanyakan. Insiden kambuh pasien skizofrenia adalah tinggi, yaitu berkisar 60\%-75\% setelah suatu episode psikotik jika tidak diterapi. Robinson juga melaporkan angka yang sama (74\%) pada pasien yang tidak teratur minum obat. Dari $74 \%$ pasien skizofrenia yang kambuh, 71\% di antaranya memerlukan rehospitalisasi (Dewi, 2009).

Skizofrenia merupakan penyakit mental yang sangat serius, karena jika tidak ditangani secepatnya, maka hal tersebut bisa menyebabkan si pengidap stress, bahkan melakukan bunuh diri. Menurut Selviana (2020), penyakit ini disebabkan oleh gangguan konsentrasi neurotransmiter otak, perubahan pada reseptor sel-sel otak, dan kelainan otak struktural, dan bukan karena alasan psikologis. Pasien akan memiliki pemikiran, perasaan, emosi, ucapan, dan perilaku yang tidak normal, yang memengaruhi kehidupan, pekerjaan, kegiatan sosial, dan kemampuan untuk mengurus diri mereka sehari-hari. Beberapa pasien bersifat rentan dan mencoba atau melakukan tindakan bunuh diri jika sudah parah sekali. Tingkat kekambuhannya sangat tinggi jika tidak dilakukan tindakan pengobatan dan perawatan yang tepat.

Pasien yang rentan terhadap penyakit ini biasanya orang-orang yang anggota keluarganya mempunyai riwayat penyakit skizofrenia, begitu juga bayi yang semasa dalam kandungan terkenal virus dari luar, ataupun penyalahgunaan obat-obat terlarang atau yang bisa disebut juga dengan pengguna narkoba. Akan tetapi, pengidap skizofrenia bisa saja terjangkit akibat faktor lingkungan yang tidak memungkinkan dikarenakan oleh tekanan yang dihadapi di sekitarnya, 
seperti contohnya korban bully, korban kekerasan seksual, maupun tekanan lain yang disebabkan lingkungan.

Dalam mencegah skizofrenia, sebetulnya tidak ada cara yang efektif dalam menanggulangi masalah ini. Akan tetapi, bisa dicoba dengan menjauhi narkotika agar tidak mengkonsumsi obatobatan terlarang yang mampu memacu delusi atau halusinasi seseorang setelah mengonsumsinya dengan dosis yang sangat banyak, dan juga jauhkan dari keadaan lingkungan yang stress, jika orang tersebut hidup di lingkungan yang stress dan penuh tekanan, ditakutkan hal tersebut sebagai pemacu sebagai penekanan diri sendiri dan menjadi pribadi yang tidak baik dengan cara memikul beban stress tersebut sendirian dan tidak terbuka dengan yang lainnya.

Pada umumnya, di ilmu kedokteran sendiri skizofrenia memiliki ciri khas tersendiri dalam gejala-gejala yang ditimbulkan oleh pasiennya sendiri. Antara lain gejalanya tersebut meliputi gangguan pikiran, delusi, halusinasi, efek abnormal, dan juga gangguan kepribadian motorik (Zahnia dan Sumekar, 2016: 164). Memang dalam penyakit gangguan jiwa atau psikologis ada banyak sekali gejala-gejala seperti halusinasi dan delusi, akan tetapi skizofrenia mempunyai ciri tersendiri dalam penyakit tersebut, karena penyakit ini sampai sekarang pun hampir belum dipastikan penyebab yang sebenarnya kenapa pasien mengidap gangguan jiwa ini di samping dari faktor genetik atau keluarga (Dr. S F HUNG:2016).

\section{Definisi Umum Semiotika}

Secara etimologis istilah semiotik berasal dari kata semeion (Yunani) yang berarti tanda. Tanda itu sendiri didefinisikan sebagai sesuatu yang dasar konvensi sosial yang terbangun sebelumnya dan dapat dianggap mewakili sesuatu yang lain (Eco, 1976:16). Sementara menurut Van Zoest (1993:1) menjabarkan semiotika sebagai "Ilmu tanda, cabang ilmu yang berurusan dengan pengkajian tanda dan segala sesuatu yang berhubungan dengan tanda, seperti sistem tanda dan proses yang berlaku bagi penggunaan tanda".

Jadi bisa diartikan jika semiotika adalah suatu ilmu atau kajian yang mempelajari suatu tanda, arti suatu tanda dan juga kegunaan dari suatu tanda tersebut. Tanda memiliki bentuk yang sangat beragam sekali dan begitu juga dengan arti yang terkandung pada tanda tersebut. Hanya karena sebuah tanda bentuknya sama, belum tentu juga mempunyai arti yang sama, karena setiap tanda mempunyai arti yang masing-masing berbeda juga tergantung dimana penempatan tanda tersebut dan apa sebabnya tanda tersebut berada di tempat itu.

Menurut Ferdinand de Saussure, sebagai pencetus ilmu semiotika dan dikatakan sebagai peletak dasar ilmu semiotika, konsep dari semiotika itu sendiri berasal dari seperangkat konsep dikotomis yang khas menurut Saussure. Contohnya adalah konsep langue dan parole, sintagmatik dan paradigmatic, serta penanda atau petanda. Namun yang paling terkenal dari pemikiran Saussure ini adalah sebagai Penanda (Signifier) dan Petanda (Signified) (dalam Sukarwo: 2019).

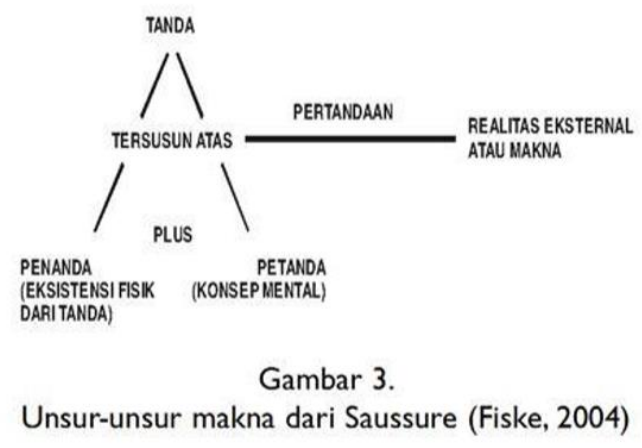

Pada pendekatan semiotika visual, konsep dikotomis signifier dan signified adalah yang paling lazim dan sering sekali digunakan oleh para pengkaji semiotika yang khususnya semiotika yang beraliran strukturalisme. Serta konsep langue dan parole sering sekali digunakan dalam mengkaji atau menilai suatu tanda karena pada umumnya suatu arti dari tanda mempunyai artinya 
yang sangat beragam dan itu tergantung dari apa yang orang lihat karena pada dasarnya setiap orang atau audience mempunyai persepsi mereka masing-masing yang pastinya mempunyai arti yang berbeda di setiap pendapat yang diutarakannya.

Tanda bukan hanya simbol, tetapi semua hal yang mengandung suatu arti bisa juga disebut sebuah tanda. Karena segala hal yang mempunyai arti, pasti diawali oleh sebuah tanda yang mempunyai sebabnya sendiri kenapa hal tersebut disebut tanda dan apa maknanya dibalik sesuatu tersebut. Sebagai contoh sebuah lukisan, lukisan mempunyai banyak sekali gabungan tanda yang berkumpul jadi satu hingga menghasilkan sebuah karya yang dapat dinikmati dengan cara dilihat dan mempunyai artinya sendiri. Warna, garis, bentuk, tekstur semuanya menjadi satu dan membentuk satu kesatuan tanda yang mempunyai banyak arti di dalamnya atau pesan yang tersirat untuk penikmat seni yang melihat karya tersebut dan dianalisis menggunakan ilmu semiotika visual, sebagai ilmu yang mempelajari tentang tanda dan juga persepsi dari berbagai pendapat yang diutarakan oleh penikmat seni tersebut dari melihat sebuah karya yang tergabung dari sekian banyak tanda sehingga menciptakan suatu karya seni yang indah yang mempunyai banyak sekali arti bagi di pencipta seni, maupun untuk penikmat seni itu sendiri.

\section{Hubungan Semiotika dengan Skizofrenia}

Munculnya konsep 'ketaksadaran' (unconsciousness) dari pencetus bapak psikologi dunia Sigmund Freud di awal abad ke-20 banyak mempengaruhi proses kreatif para seniman di Barat pada masa itu yang aktif mencari nilai-nilai kebaruan dan mengeksplorasi kekuatan kreativitas berdasarkan intuisi, nalar. dan kepekaan rasa. Pengaruh pemikiran Freud terlihat jelas pada karyakarya seni lukis bergaya Surrealis. Ekspresionis. Abstrak-Ekspresionis dan kegiatan eksplorasi kualitas ekspresi yang spontan dan otomatis (Tridjata dan Piliang, 2015). Dari ketidaksadaran tersebutlah mampu menciptakan suatu karya ntah menjadi sebuah lukisan, puisi, atau hal lainnya yang bisa dirasakan oleh pengamat karya tersebut.

Eksplorasi kualitas spontanitas dalam ekspresi karya bukan hanya dilakukan oleh para seniman saja namun juga oleh kalangan 'nonartist', seperti halnya para penyandang skizofrenia. Terkait dengan hal ini, maka para penyandang psikotik yang tergabung dalam Yayasan Komunitas Peduli Skizofrenia Indonesia (KPSI) secara aktif melakukan eksplorasi perasaan, emosi, imajinasi dan fantasi mereka melalui aktivitas menggambar dan melukis demi mendapatkan suatu hal yang mereka tuju, yaitu mengekspresikan yang mereka rasa melalui seni. Di sini tampak ada spirit, fantasi, kreativitas, harapan dan potensi tersembunyi di dalam diri mereka yang memerlukan penyaluran agar dapat termanifestasi dan tersalurkan sehingga menjadi karya-karya seni yang dapat di apresiasi oleh masyarakat luas dan penikmat seni di tanah air. Perkembangan riset humanistik terkini khususnya di bidang psikoanalitik menaruh perhatian pada persoalan keragaman kategori fenomena "emosi". Penelitian tentang emosi yang kini popular diteliti khususnya berkaitan dengan unsur-unsur generik, keterkaitan emosi dengan karya seni dan berbagai penyakit yang berkaitan dengan faktor 'desire' dan 'pleasure' (Carroll, 2001:215-216).

Penggunaan metode semiotika yang meluas saat ini dan banyak dimanfaatkan dalam pembacaan karya-karya seni rupa kontemporer dipandang relevan untuk memahami keunikan tanda-tanda visual yang merefleksikan "self-expression" (ekspresi diri) dari individu dengan masalah psikosis, seperti skizofrenia. Karena, karya-karya lukis yang mereka hasilkan umumnya merupakan ekspresi dari perasaan, pikiran dan pengalaman ketaksadaran (unconscious) yang merefleksikan masalah psikologis yang dialaminya, serta tidak jarang juga dari karya seni tersebut kita mampu mengetahui atau menganalisa apa yang dirasa oleh pengidap skizofrenia dan juga hal apa yang membuat sang pengidap mampu terkena penyakit jiwa tersebut lewat dari warna, garis, objek, bentuk dari karya seni yang mereka hasilkan.

Ungkapan yang populer di kalangan para terapis seni adalah 'draw from within' yang dapat diartikan sebagai 'menggambar dari dalam diri', bukan menggambar dari apa yang dilihat. Hal ini cenderung untuk menggambar sesuatu dari kondisi yang dirasakan oleh si pengidap dan mencurahkan hal tersebut lewat karya berdasarkan yang mereka alami sendiri dan perasaan mereka sendiri. Fenomena ini sejalan dengan apa yang dikatakan Aristoteles "seni membebaskan tekanan-tekanan yang tidak disadari" dan pernyataan ini berkaitan erat dengan teori "katarsis". 
Proses katarsis melibatkan proses transformasi emosi yang tertekan dan tersembunyi dalam ketaksadaran masuk ke tingkat kesadaran sehingga membuat penyandang mampu merasakan perasaan yang mereka alami secara sadar. Sublimasi artistik yang dilakukan oleh penyandang skizofrenia memberi pengaruh positif dalam membangkitkan respons "cathartic pleasure" yang mampu mereduksi ketegangan emosional sehingga memberi sensasi kelegaan dan penikmatan dalam diri mereka (Yasraf \& Caecilia, 2:2015). Seperti contohnya seseorang yang awalnya tidak tau untuk menceritakan masalahnya kepada siapa, tetapi ketika orang tersebut mampu mengeluarkan semua uneg-unegnya kepada orang yang tepat, orang tersebut akan merasakan hal yang sama dengan "cathartic pleasure" di atas, yaitu kelegaan dan merasa tidak terbebani dalam hidupnya.

\section{Contoh Karya Seni Pengidap Skizofrenia}

Tak jarang jika pasien skizofrenia mempunyai kesulitan dalam mencurahkan isi hati atau apa yang ada di dalam pikirannya, dikarenakan dengan penuhnya tekanan yang mereka alami dalam setiap harinya dan beban yang mereka rasakan. Pengidap skizofrenia memang sangat susah sekali dalam menyampaikan apa isi pikirannya atau bisa dibilang sangat sulit untuk berpikiran jernih, karena mereka seperti merasakan ada banyak sekali bisikan di dalam pikiran mereka sehingga mereka sangat sulit untuk menentukan mana akal pikiran yang benar dan sesuai dengan tujuannya maupun keinginannya.

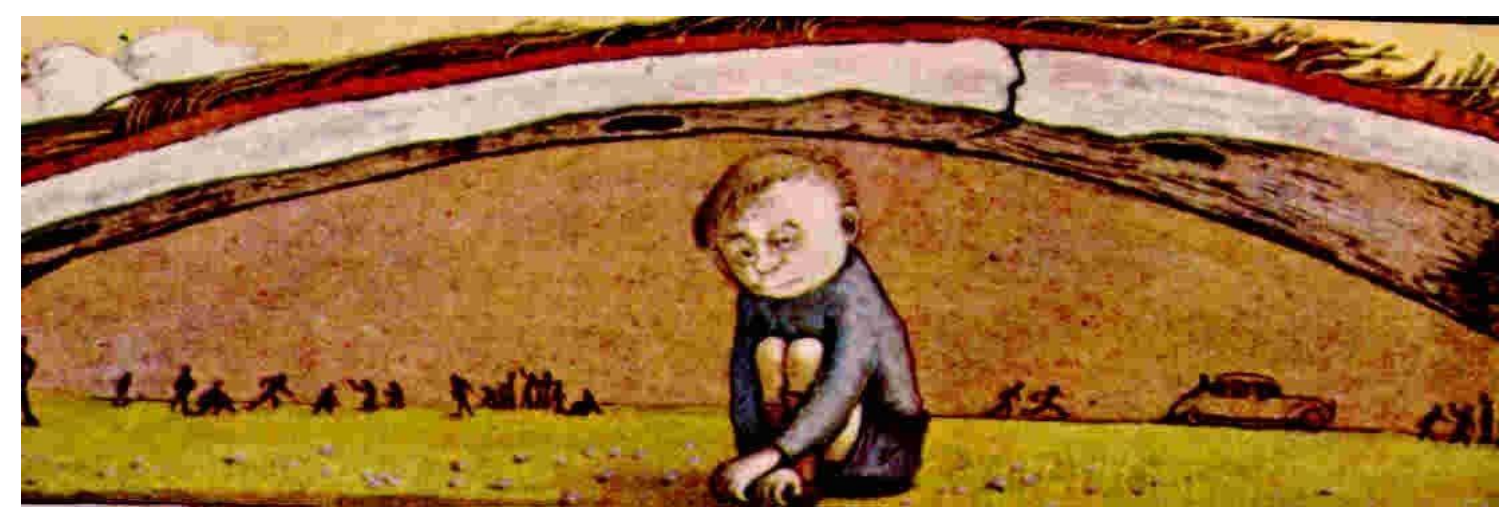

Gambar 1 "Labirin" karya Derek Bayes

Lukisan ini dibuat oleh Derek Bayes yang merupakan pasien skizofrenia yang berusia 25 tahun. Derek Bayes dibesarkan di ladang di dataran Kanada dan semasa kecil, dia mengalami masa kecil yang sangat keras sekali. Sehingga menjadikannya sebagai orang yang benar-benar pemalu dan menjadikan dirinya sebagai pribadi yang tertutup. Dia mencari tempat berlindung dari fantasi-fantasi anehnya. Dengan penyakit skizofrenia yang ia idap itu, ia menjadi sangat introvert atau penyendiri karena perbedaan yang ada di dalam dirinya itu. Berikut ini adalah analisis kami mengenai karya lukisan dari Derek Bayes tersebut.

Pada analisis kali ini, kami menggunakan pendekatan semiotika dengan menggunakan metode Signifiant (Penanda) dan Signifie (Petanda) dari Ferdinand de Saussure. Karena menurut kami pendekatan ini sangat pas sekali dalam menilai suatu visual yang dikarenakan Signifiant berarti tanda yang secara keseluruhan tidak dapat dipisahkan dan memang sudah menjadi satu kesatuan dalam suatu tanda, dan hal tersebut mencerminkan sebagai suatu lukisan yang merupakan kumpulan dari elemen desain yaitu titik, garis, bentuk, tekstur, ruang, bidang, ukuran dan warna yang dijadikan satu karya sehingga terciptalah karya visual sehingga lukisan menjadi Signifiant. Dan Signifie sendiri merupakan hasil dari kesimpulan yang kita dapatkan atau kita rasakan ketika kita menganalisis karya tersebut dari warna, bentuk, objek dan yang kita lihat dari lukisan tersebut sehingga kita mampu menciptakan persepsi masing-masing dalam menilai suatu arti dari karya visual itu sendiri. 
Dalam lukisan Derek Bayes terlihat seperti lapangan yang luas dan terdapat seperti bukit yang tinggi. Objek yang sangat jelas adalah seorang anak seumuran remaja sedang duduk termenung di antara keramaian dengan gambar orang - orang yang hanya terlihat bentuknya saja. Adapun warna yang terdiri antara lain hijau, cokelat, putih dan merah serta warna kulit yaitu cream. Dari warna yang terlihat pada lukisan ini yaitu warna-warna yang pada umumnya selalu di gunakan, namun yang unik yaitu pada gambar bukit terlihat seperti gambar lengkungan tulang yang retak atau patah. Dari penekanan yang terlihat yaitu pada gambar remaja yang sedang duduk di tengah dengan wajah muram.

Jika ditelaah dan dianalisis lebih dalam lagi, sebenarnya lukisan tersebut mempunyai arti yang sangat dalam sekali dan memang mengharukan. Dalam lukisan tersebut terdapat bentuk seperti bukit dengan 4 warna, yaitu diawali dengan bentuk serabut warna coklat pada lapisan pertama, warna merah dilapisan kedua, warna putih dengan adanya motif retak pada bagian tersebut, dan yang terakhir adalah warna coklat muda seperti lapisan pertama dan bagian bukit tersebutlah yang kami yakini sebagai Signifiant, karena hal tersebut merupakan kumpulan dari tanda dengan bentuk dan juga warna yang digabung menjadi satu. Jika diasumsikan dengan metode Signifie, bagian tersebut bisa diibaratkan sebagai bagian kepala, dan kami yakin jika bagian kepala tersebut merupakan visual dari kepala Derek Bayes itu sendiri. Bagian tersebut jika dijelaskan secara rinci maka dapat dikatakan sebagai lapisan pertama merupakan rambut dari kepala tersebut, warna merah merupakan darah yang mengalir di sekitar kepala tersebut, warna putih merupakan tulang tengkorak dari kepala tersebut, dan mengenai retakan pada bagian tersebut, kami berasumsi bahwa mungkin Derek pernah mengalami kecelakaan sehingga mengakibatkan retak pada bagian tulang tengkoraknya pada semasa kecil dikarenakan mengalami hidup yang sangat berat, ntah fisik maupun secara batin.

Namun asumsi kami juga mengatakan bahwa retak pada bagian putih tersebut dapat juga diibaratkan sebagai penuhnya pola pikir yang dipikirkan oleh si Derek ini, sehingga objek yang diasumsikan sebagai tulang tengkorak tersebut tidak dapat menampung lagi semua perasaan atau uneg-uneg yang dirasakan oleh Derek itu sendiri, sehingga pada bagian tersebut ada pola retak yang diakibatkan karena penuhnya stress dan depresi yang dialami oleh Derek pada semasa hidupnya saat kecil bahkan sampai sekarang karena hal tersebut dikatakan sebagai trauma yang dialami oleh Derek semasa hidupnya hingga sekarang.

Dan di dalam lapisan tersebut, terlihat ada seorang anak kecil yang menjadi pusat perhatian di sana karena sedang termenung dan ekspresi yang sedih dengan suasana langit yang berwarna cokelat muda namun pucat juga seperti suasana yang kelam pada lukisan tersebut. Begitu juga dengan background figure manusia di belakang anak tersebut, ada figure yang terlihat sedang bermain dengan temanya, ada yang terlihat seperti mem-bully tamannya, ada juga yang terlihat seperti sedang berlibur dengan keluarga atau teman-temannya yang diibaratkan dengan figure mobil dibelakang anak tersebut. Dan hal tersebut lah yang kami jadikan sebagai Signifiant pada analisis bagian ini, dikarenakan bagian tersebut memiliki banyak sekali tanda yang memang sudah menjadi suatu kesatuan di karya tersebut. Yaitu dari objek anak yang ditengah sebagai eye of interest dari lukisan tersebut, dan juga dengan figure yang berada di background dari anak tersebut, dan warna menyelimuti suasana tersebut dan menjadi satu.

Dari analisis Signifiant (penanda) pada beberapa bagian yang ada pada lukisan tersebut, mungkin dapat diasumsikan Signifie (petanda) sebagai pribadi Derek yang tertutup dan introvert dikarenakan kelainan skizofrenia yang ia alami, sehingga ia menjadi pribadi yang pemalu juga penyendiri dalam setiap harinya untuk objek anak yang sedang duduk termenung di tengah area. Dan mungkin juga, karena kelainan skizofrenia yang ia alami, hal tersebut membuat Derek dijauhi oleh teman-teman seusianya (yang ditandai sebagai Signifiant dengan banyaknya figure anak pada background) pada masa itu karena dianggap tidak normal sehingga Derek pun mengalami stress berat dan lebih memilih untuk menjadi pribadi yang pemurung dan penyendiri lalu menjauh dari masyarakat. Untuk warna langit yang melapisi bagian dalam tulang tengkorak tersebut yang kami tandai pula sebagai Signifiant dalam warna, dapat diasumsikan Signifie yang juga sebagai situasi masa kelam yang dialami oleh Derek. Karena warna pucat yang lebih dominan pada bagian visual tersebut, maka dapat diartikan juga sebagai suasana yang suram dan kelam bagi masa 
hidupnya Derek yang dari kecil sudah mengalami hidup yang sangat keras dan dijauhi oleh temantemannya, dan hal tersebut sampai sekarang tersimpan sebagai memori yang sangat kelam bagi Derek dan hal tersebut lah yang mungkin dapat menjadi sebab mengapa Derek dapat mengidap skizofrenia dan stress berat, sehingga membuatnya menjadi pribadi yang seperti sekarang, dikarenakan oleh masa lalunya yang sangat kelam.

\section{SIMPULAN}

Dari hasil penelitian yang sudah kami telaah dan analisis diatas, maka kesimpulannya adalah penyakit skizofrenia merupakan suatu penyakit jiwa yang sangat serius, dikarenakan penyakit jiwa ini mampu membuat seseorang menjadi pribadi yang sangat berbeda dan akan sangat sulit sekali untuk ditangani jika dibiarkan lebih lama lagi karena dapat menyebabkan sang pengidap untuk bunuh diri. Meskipun penyebabnya masih belum ditemukan selain dari faktor genetik atau keluarga, namun kami dapat berasumsi jika stress, masa lalu yang kelam, dan kehidupan yang sangat keras dapat menyebabkan stress berat dan mampu menimbulkan penyakit jiwa seperti ini jika dibiarkan dan tidak ditangani oleh pihak yang professional.

Meskipun skizofrenia merupakan penyakit yang sangat sulit sekali untuk dijabarkan bagi si pengidap, namun dengan media lukisan atau visual yang dapat kita liat dari karya si pengidap tersebut. Kita dapat berasumsi menggunakan teori semiotika dari Ferdinand de Saussure dengan metode signifiant dan signifie untuk mengetahui apa yang ada di pikiran si pengidap melalui hasil karya tersebut, bisa saja itu sebagai pemacu hal penyebab mengapa ia bisa terkena skizofrenia, ataupun hanya sekadar mengekspresikan diri melalui media visual sehingga kita mampu mengerti apa yang mereka rasakan. Karena dibalik setiap tanda lukisan (signifiant) pasti ada arti (signifie) yang tersirat di dalamnya.

\section{DAFTAR PUSTAKA}

Carroll, N. (2001). Beyond aesthetics: Philosophical essays. Cambridge University Press.

Fatmawati, I. N. A. (2016). Faktor-faktor penyebab skizofrenia (studi kasus di rumah sakit jiwa daerah surakarta) (Doctoral dissertation, Universitas Muhammadiyah Surakarta).

Fu'ady, M. A. (2011). Dinamika psikologis kekerasan seksual: Sebuah studi fenomenologi. Psikoislamika: Jurnal Psikologi dan Psikologi Islam, 8(2).

Kamus Besar Bahasa Indonesia. Jiwa. Diakses dari https://kbbi.kemdikbud.go.id/entri/jiwa

Kurniawan, F. (2016). Gambaran Karakteristik pada Pasien Gangguan Jiwa Skizofrenia di Instalasi Jiwa RSUD Banyumas tahun 2015 (Doctoral dissertation, Universitas Muhammadiyah Purwokerto).

Mathar, H. (2015). Semiotika Visual (Sebuah kajian tentang ilmu tanda dalam kebudayaan kontemporer).

Murtono, T. (2010). Mengenal semiotika desain komunikasi visual. Capture: Jurnal Seni Media Rekam, 1(2).

Sugiyono, P. (2011). Metodologi penelitian kuantitatif kualitatif dan R\&D. Bandung: Alpabeta.

Sukarwo, W. (2019). Semiotika visual: Penelusuran konsep dan problematika operasionalnya. Jurnal Desain, 1(01), 69-77.

Tinarbuko, S. (2003). Semiotika analisis tanda pada karya desain komunikasi visual. Nirmana, 5(1). 
Tridjata, C., \& Piliang, Y. A. (2015). Semiotika Ketaksadaran pada Karya Lukis Penyandang Skizofrenia Residual. RITME, 1(1), 10-19.

Tunjungsari, P. (2011). Pengaruh stres kerja terhadap kepuasan kerja karyawan pada kantor pusat PT. Pos Indonesia (Persero) Bandung. Jurnal Fakultas Ekonomi Universitas Komputer Indonesia, 1(1), 1-14.

Zahnia, S., \& Sumekar, D. W. (2016). Kajian epidemiologis skizofrenia. Jurnal Majority, 5(4), 160-166. 